\title{
IMPLEMENTASI STRATEGI PEMBELAJARAN AKTIF DALAM PELAJARAN AGAMA HINDU
}

Oleh : Putu Sri Junianti

\begin{abstract}
On each there are teaching objectives to be achieved and for the achievement of these goals we need to convey topics in it there are concepts that should be up on the students, and for that particular approach is required as the solution problem solved, latiahan, trainer-memorized and possibly with other approaches. In a lesson that corresponds to a particular principle of curriculum material keterlaksanaan dipenggaruhi by four principal components, namely the carrier material, the Publisher materials, approaches and materials. In general the process of learning oriented activities on achieving a competency, hinting that Hindu religious educators should seoang mastered a number of capabilities regarding planning, how to organize and process implementation the learning itself. Active learning methods, positioning is one of the methods of positioning an educator to be able to dig into the potential that exists in his protégé so that participants can build creativity in the learning process. The application of active learning methods is an urgency that must be implemented by each school, this is because, the development of the educational world now demands the students become active and creative in the learning process.
\end{abstract}

Keywords: strategy, active learning, and the education system

\section{Pendahuluan}

Salah satu fungsi guru adalah meningkatkan mutu dan kualitas pembelajaran yang ditetapkan dalam kegiatan proses belajar dan mengajar dengan mengembangkan dan menganalisa kurikulum yang berlaku. Sebelum masuk ke strategi pembelajaran menurut Hindu, perlu diawali dengan memahami makna dari apa yang dimaksud dengan strategi pembelajaran. Strategi adalah usaha untuk memperoleh kesuksesan dan keberhasilan dalam mencapai tujuan. Strategi pembelajaran dapat diartikan sebagai perencanaan yang berisi tentang rangkaian kegiatan yang didesain untuk mencapai tujuan pendidikan. Strategi pembelajaran merupakan rencana tindakan (rangkaian kegiatan) termasuk 
penggunaan metode dan pemanfaatan berbagai sumber daya atau kekuatan dalam pembelajaran yang disusun untuk mencapai tujuan tertentu, dalam hal ini adalah tujuan pembelajaran. Kemp (1995) menjelaskan bahwa strategi pembelajaran adalah suatu kegiatan pembelajaran yang harus dikerjakan guru dan siswa agar tujuan pembelajaran dapat dicapai secara efektif dan efisien.

Pada umumnya kegiatan proses pembelajaran yang berorientasi pada pencapaian suatu kompetensi, mengisyaratkan bahwa seoang guru Pendidik Agama Hindu hendaknya menguasai sejumlah kemampuan mengenai perencanaan, cara mengorganisasi dan pelaksanaan proses pembelajaran itu sendiri. Karena itu maka seorang guru dapat memperkaya wawasan terhadap klasifikasi sistem pembelajaran yang ingin diterapkan ke dalam kegiatan proses pembelajaran Pendidikan Agama Hindu sesuai dengan kurikulum. Untuk mencapai tujuan pembelajaran yang optimal dan efisien serta efektif, maka seorang guru harus menetapkan strategi pembelajaran yang akan diterapkannya.

\section{Pembahasan}

\subsection{Pengertian Strategi Pembelajaran Aktif}

Strategi adalah usaha untuk memperoleh kesuksesan dan keberhasilan dalam mencapai tujuan. Strategi pembelajaran dapat diartikan sebagaiperencanaanyangberisitentangrangkaian kegiatan yang didesain untuk mencapai tujuan pendidikan. Strategi pembelajaran merupakan rencana tindakan (rangkaian kegiatan) termasuk penggunaan metode dan pemanfaatan berbagai sumber daya atau kekuatan dalam pembelajaran yang disusun untuk mencapai tujuan tertentu, dalam hal ini adalah tujuan pembelajaran.

Secara umum strategi mempunyai pengertian suatu garis-garis besar haluan untuk bertindak dalam usaha mencapai sasaran yang telah ditentukan. Dihubungkan dengan belajar mengajar, strategi bisa diartikan sebagai pola-pola umum kegiatan guru anak didik dalam perwujudan kegiatan belajar mengajar untuk mencapai tujuan yang telah digariskan (Djamarah:1997:5). Pembelajaran aktif merupakan suatu pembelajaran yang menekankan kepada siswa untuk dapat berperan aktif selama proses pembelajaran, pembelajaran akan lebih aktif dan efektif apabila ditunjang dengan berbagai fasilitas-fasilitas yang mendukung, tata letak yang nyaman dan gaya belajar yang bervariasi.

Pembelajaran aktif menurut Hisyam Zaini adalah suatu pembelajaran yang mengajak siswa untuk belajar secara aktif (Zaini:2004:16) karena disaat siswa mulai untuk berkonsentrasi memasuki pembelajaran aktif maka mereka telah mulai untuk dapat mendominasi aktivitas pembelajaran yang disampaikan oleh guru, sehingga materi dapat mudah untuk dihayati dan dipraktekkan oleh siswa. Dan pembelajaran aktif menurut Moh.Uzer Usman adalah suatu strategi belajar mengajar yang lebih menekankan pada keaktifan siswa dalam kegiatan belajar mengajar baik secara fisik, mental, intelektual maupun emosional (Usman:2000:87) Dan telah kita ketahui bersama bahwa suatu pembelajaran 
aktif itu akan dapat berjalan dengan baik apabila seorang guru disini dapat bertindak sebagai fasilitator yang baik dan selebihnya murid yang berperan aktif dalam proses belajar mengajar karena ini akan dapat memudahkan siswa dalam memahami materi.

Sedangkan pembelajaran aktif menurut Oemar Hamalik adalah suatu cara belajar yang dilakukan dengan melakukan pendekatan belajar inkuiri yaitu cara belajar mengajar yang dimaksudkan untuk dapat mengembangkan keterampilan yang dimilki siswa dalam memecahkan masalah dengan menggunakan pola berpikir secara kritis(Oemar:1990:18) Dengan cara ini berinovasi mengembangkan keterampilan yang dimiliki.

Dari setiap kegiatan dan pembelajaran aktif menuntut keterlibatan intelektual dan emosional siswa dalam proses pembelajaran melalui asimilasi dan akomodasi kognitif untuk dapat mengembangkan pengetahuan tindakkan serta pengalaman langsung dalam rangka membentuk keterampilan motorik, kognitif dan sosial, penghayatan serta iternalisasi dalam pembentukan sikap siswa. Pembelajaran aktif adalah suatu proses pembelajaran yang tujuannya untuk memberdayakan peserta didik agar belajar menggunakan berbagai cara atau strategi secara aktif. Pembelajaran aktif dimaksudkan untuk mengoptimalkan penggunaan semua potensi yang dimiliki oleh siswa, sehingga semua siswa dapat mencapai hasil belajar yang memuaskan sesuai dengan karakteristik pribadi yang mereka miliki. Di samping itu pembelajaran aktif juga dimaksudkan untuk menjaga perhatian siswa agar tetap tertuju pada kegiatan pembelajaran. Mendidik dengan ceramah berarti memberikan satu informasi melalui pendengaran, yang hanya bisa dicerna oleh otak siswa (20\%). Padahal informasi yang dipelajari siswa bisa saja dari membaca (10\%), melihat (30\%), melihat dan mendengar (50\%), mengatakan (70\%), mengatakan dan melakukan (90\%). Hal ini sesui dengan pendapat Konfusius dalam bukunya Melvin L. Siberman sebagai berikut:

1. Yang saya dengar, saya lupa.

2. Yang saya dengar dan lihat, saya sedikit ingat.

3. Yang saya dengar, lihat dan pertanyaan/ diskusikan dengan orang lain saya mulai paham.

4. Dari yang saya dengar, lihat, bahas dan terapkan saya dapatkan pengetahuan dan keterampilan. Yang saya ajarkan kepada orang lain saya kuasai. (Raisul, 2004:1)

Pernyataan ini menekankan pada pentingnya belajar aktif agar apa yang dipelajari di bangku sekolah tidak menjadi suatu hal yang sia-sia. Ungkapan di atas sekaligus menjawab permasalahan yang sering dihadapi dalam proses pembelajaran, yaitu tidak tuntasnya penguasaan siswa terhadap materi pembelajaran. Aktifitas siswa belajar di kelas terwujud bila terjadi interaksi antar warga kelas. Di dalam interaksi ada aktifitas yang bersifat resiprokal (timbal balik) dan berdasarkan atas kebutuhan bersama, ada aktifitas daripada pengungkapan perasaan, dan ada hubungan untuk tukar- 
menukar pengetahuan yang didasarkan take and give, yang semuanya dinyatakan dalam bentuk tingkah laku dan perbuatan. hubungan timbal balik antar warga kelas yang harmonis dapat merangsang terwujudnya masyarakat kelas yang gemar belajar. Dengan demikian, upaya mengaktifkan siswa belajar dapat dilakukan dengan mengupayakan timbulnya interaksi yang harmonis antar warga di dalam kelas. Interaksi ini akan terjadi bila setiap warga kelas melihat dan merasakan bahwa kegiatan belajar tersebut sebagai sarana memenuhi kebutuhannya. Dalam kaitannya dengan proses pembelajaran, berdasarkan teori kebutuhan.

Dari pembahasan di atas, tip - tip dibawah ini dapat digunakan guru untuk mengarah pada strategi pembelajaran yang dapat mengaktifkan siswa dalam belajar:

1. Selalu berpenampilan menarik dan penuh wibawa.

2. Manfaatkan pertemuan pertama dengan siswa untuk perkenalan antar warga kelas.

3. Buatlah formasi

4. Siapkan semua peralatan yang akan digunakan di dalam ruang kelas sebelum memulai pembelajaran.

5. Mulailah proses belajar mengajar dengan materi yang ringan tetapi menantang yang dapat merangsang siswa turut aktif berfikir.

6. Selalu memulai dan mengakhiri pembelajaran tepat waktu serta dengan salam yang menghangatkan.
7. Gunakan bahasa yang santun, hormat, dan dengan nada bicara yang lembut.

8. Memahami dan menghormati berbagai perbedaan yang ada.

9. Menghormati kerahasiaan setiap siswa.

10. Tidak merendahkan dan mencemooh siswa.

11. Memberi kesempatan yang sama kepada semua siswa untuk bicara dan jangan mengintrupsi pembicaraan siswa.

12. Bila seorang siswa mengemukakan pendapat, jadilah pendengar yang baik dan selanjutnya berikan kesempatan kepada siswa lain untuk memahaminya dan memberikan komentarnya.

13. Memahami dan menghormati pendapat setiap siswa, bila perlu melancarkan kritik: gunakan bahasa yang mengayomi, dan bila kritik bersifat pribadi seyogyanya dilakukan di ruang khusus.

14. Sekali waktu, berilah kesempatan kepada siswa untuk memberikan saran atau kritik guna perbaikan proses pembelajaran.

15. Sediakan waktu untuk berkomunikasi dengan siswa di luar kelas.

Pembelajaran pada dasarnya merupakan pemberian stimulus kepada siswa, agar terjadilah respons yang positif pada diri siswa. Kesediaan dan kesiapan mereka dalam mengikuti proses belajar mengajar akan mampu menimbulkan 
respons yang baik terhadap stimulus yang mereka terima dalam pembelajaran. Respons akan menjadi kuat jika stimulusnya juga kuat. Hubungan antara stimulus dan respons akan menjadi lebih baik kalau dapat menghasilkan halhal yang menyenangkan. Efek menyenangkan yang ditimbulkan stimulus akan mampu memberi kesan yang mendalam pada diri siswa, sehingga mereka cenderung akan mengulang aktivitas tersebut. Akibat dari hal ini adalah siswa mampu mempertahan stimulus dalam memory mereka dalam waktu yang lama (longterm memory), sehingga mereka mampu merekam apa yang mereka peroleh dalam pembelajaran tanpa mengalami hambatan apapun.

Dalammetodeactivelearning(belajaraktif) setiap materi pelajaran agama harus dikaitkan dengan berbagai pengetahuan dan pengalaman yang ada sebelumnya. Materi pelajaran yang baru disediakan secara aktif dengan pengetahuan yang sudah ada. Agar murid dapat belajar secara aktif guru perlu menciptakan strategi yang tepat guna sedemikian rupa, sehingga peserta didik mempunyai motivasi yang tinggi untuk belajar. Belajar aktif pada dasarnya berusaha untuk memperkuat dan memperlancar stimulus dan respons siswa dalam pembelajaran, sehingga pembelajaran menjadi hal yang menyenangkan, tidak menjadi hal yang membosankan bagi siswa. Dengan memberikan strategi belajar aktif pada siswa dapat membantu ingatan (memory) mereka, sehingga mereka dapat dihantarkan kepada tujuan pembelajaran dengan sukses. Hal ini kurang diperhatikan pada pembelajaran konvensional.

\subsection{Prinsip Pembelajaran Aktif}

Prinsip pembelajaran aktif adalah suatu proses pembelajaran yang lebih menekankan pada siswanya untuk dapat aktif dalam mengembangkan bakat keterampilan, mengasah pengetahuannya dan menciptakan suasana belajar terdiri bagi dirinya sehingga akan tercipta suasana belajar yang lebih nyaman dan lebih mudah dalam memahami pelajaran yang disampaikan oleh guru. Prinsip pembelajaran aktif menurut Melvin L. Silberman:

\section{a. Memperkenalkan belajar aktif}

Sebelum kita menjadikan siswa untuk aktif dalam mempelajari materi yang disajikan untuk pendidik maka terlebih dahulu pendidik memperkenalkan tentang pembelajaran aktif yang dimaksud. Agar siswa tahu dan faham maksud dan tujuan yang dicapainya. Tidak hanya tempat untuk menerima informasi tetapi juga tempat mengolah informasi. Dan untuk dapat mengolah informasi secara efektif maka perlu perenungan secara eksternal dan internal. Otak akan dapat bekerja, apabila kita satu sama lain saling bertukar informasi dengan orang lain untuk membahas informasi yang didapat dengan begitu otak akan lebih menerima materi dan diselingi.

Dalam pembelajaran aktif yang selalu teringat dalam pikiran kita adalah metode belajar sambil bermain yang banyak menyita waktu, namun pada intinya pembelajaran aktif itu tidak hanya suatu metode belajar sambil bermain saja tapi itu merupakan salah satu yang digunakan agar lebih tercipta suasana belajar lebih aktif, kreatif, nyaman dan tidak membosankan serta 
membuat pelajaran mudah untuk diingat dan dimengerti. Dengan kita perkenalkan metode pembelajaran aktif sebagai simple dan manarik serta nyaman akan membuat siswa tertarik untuk mempraktekkan pembelajaran aktif di setiap pelajaran kemudian dapat dikreasikan dengan keterampilan yang dimiliki.

\section{b. Menjadikan siswa aktif sejak awal}

Untuk dapat menciptakan siswa lebih aktif sejak awal maka perlu buat rencana susunan aktivitas pembuka yang menjadikan siswa lebih mengenal satu sama lain merasa lebih leluasa, ikut berpikir dan memperlihatkan minatnya terhadap pelajaran, kita perlu mamiliki tujuan yang harus dicapai seorang pendidik diantaranya adalah

1. Pembentukan Tim : Pendidik harus mampu mengenalkan mereka antara siswa satu dengan siswa lainnya dan menciptakan semangat kerja sama diantara mereka.

2. Penilaian secara sederhana : Dari bermacam-macam, pendidik harus dapat untuk mempelajari sikap, pengetahuan dan pengalaman siswa secara sederhana kemudian memberikan kesempatan pada siswa untuk bertanya sesuai dengan harapannya, sehingga akan terkesan menyenangkan bagi siswa dan tidak merasa mengancam. Dan untuk lebih mengatahui sejauh mana keaktifan siswa perlu diambil beberapa sampel dari perwakilan kelas kemudian dibuat kelompok diskusi untuk diwawancarai didepan kelas seputar pelajaran.

3. Melibatkan belajar siswa secara langsung : Pendidikan perlu menumbuhkan minat siswa terhadap pelajaran, kemudian memperkanalkan materi pelajaran yang akan diajarkan sembari pembentukan kelompok untuk menilai tingkat pengetahuan siswa secara langsung, kemudian saling bertukar pendapat antar teman sehingga kan tercipta suasana belajar yang santai, kreatif dan membuat siswa untuk lebih berpikir.

\section{c. Membantu siswa mendapatkan pengetahuan, keterampiulan dan sikap secara aktif.}

1. Kita ajak mereka masuk kedalam dunia belajar yang penuh dengan berbagai macam. Strategi-strategi untuk informasi dan gagasan yang melibatkan siswa secara langsung dan secara mental untuk bertanya kemudian kita bentuk tim pendengar yang membuat meraka bertanggung jawab, dengan metode ceramah yang telah kita modifikasi sehingga menarik untuk didengar dan membuat siswa aktif untuk bertanya sesuai dengan dunianya.

2. Debat aktif yang dimulai denagan dialog seputar persoalan-persoalan materi yang disampaikan oleh guru sebagai pemimpin debat/motivator yang melibatkan semua siswa yang ada di kelas dengan tujuan 
untuk meningkatkan pemikiran dan perenungan terutama pendapat mengnai diri mereka sendiri.

3. Pengajuan pertanyaan dalam hal ini guru membuat suatu strategi agar siswa aktif untuk bertanya maka guru tidak menjelaskan materi tetapi meminta siswa untuk mempelajari materi kemudian membuat pertanyaan untuk ditanyakan dalam pokok pembeahasan materi pelajaran tersebut. Sehingga dengan begitu akan membuat siswa aktif dalam materi.

4. Belajar bersama akan lebih efektif bila adakan kalaboratif namun akan sebaliknya apabila tidak berbagi tugas. Dalam pencarian informasi akan lebih menarik apabila diulas seperti metode ceramah, pembagian kelompok belajar akan lebih efektif bila setiap siswa dapat bertanggung jawab mempelajari materi pelajaran dan menjabarkan isinya dalam sebuah kelompok tanpa adanya campur tangan dari guru. Dan untuk lebih meningkatkan pembelajaran yang beragama, fakta konsep dan keterampilan perlu dibentuk penggabungan kelompok dan kompetisi tim. Aktivitas ini bertujuan untuk meningkatkan pembelajaran dan menegaskan manfaat dari dua kepala lebih baik dari pada satu kepala.

5. Pembelajaran antar siswa akan mampu membuat siswa lebih menguasai materi karena setiap siswa dianjurkan untuk paham materi tersebut. Kamudian baru diajarkan pada temannya dan ini dapat dikatakan siswa dapat menjadi seorang guru bagi teman-temannya, dengan begitu mereka akan lebih tekesan dengan apa yang dilakukannya sehingga membuat mereka untuk lebih berinovasi bagaimana caranya untuk dapat memahamkan teman-temannya.

6. Belajar mandiri merupakan belajar untuk mengembangkan imajinasi dalam menciptakan gagasan, member kesempatan pada diri sendiri untuk memikul tanggung jawab pribadi dari apa yang telah dipelajari bersama kelompoknya, mengingat-ingat dijadikan contoh untuk melangkah kedepan dalam mempraktekkan dalam kehidupan nyata tentang materi pelajaran yang didapatnya kemudian mempraktekkan didepan kelas. Belajar akan lebih menyenangkan dan menarik apabila keinginan itu timbul dari dalam diri sendiri, seakan kita telah terikat kontrak untuk dapat menguasainya dari pada selalu diarahkan oleh guru. Belajar dengan cara ini akan membuat nyaman dan selalu terkenang.

7. Belajar aktif merupakan salah satu aktivitas belajar yang efektif dalam membantu siswa untuk dapat mengenali perasaan, sikap dan nilai yang tertanam dalam diri siswa sehingga apa yang dilakukannya itu merupakan cerminan dari perasaannya ingin tahubuklan 
suatu kondisi yang dipaksakan. Ada banyak materi yang kita pelajari dan ajarkan pada teman dan untuk lebih menjernihkan pikiran serta menambah pengetahuan perlu kita diskusikan kembali.

8. Pengembangan keterampilan merupakan yang paling mudah untuk dipelajari untuk setiap siswa karena setiap siswa mempunyai keterampilan yang berbeda-beda dan dari keterampilan yang dipunyai guru membantuuntuk dapatmengembangkan sehingga nantinya siswa akan dapat mempraktekkan saja hanya dengan melihat, mengamati kemuudian menganalisis permasalahan yang terjadi dan dapat menyelesaikan secara bergantian pada diskusi dengan cara ini dapat memberikan kesempatan siswa untuk memprektekkan keterampilan yang dimilki dalam perannya dalam situasi diskusi.

\section{d. Menjadikan belajar tak terlupakan.}

Untuk dapat mengingat kembali pada apa yang telah lah mereka pelajari dan lebih memahamkan dan menerapkannya kemasa mendatang maka perlu teknik-teknik sebagai berikut:

1. Peninjajuan merupakan salah satu cara untuk membuat pelajaran tetap melengket dalam pikiran dengan mengalokasikan waktu untuk mengingat kembali/ meninjau apa yang telah dipelajari dengn begitu mereka akan dengan mudah untuk menyimpannya di dalam otak, dengan menggunakan cara-cara seperti layaknya suatu permainan yaitu dengan mencocokkan kartu indeks ini merupakan cara yang membuat kita aktif dan menyenangkan untuk dapat mengingatkembali cara lain dengan memberikan pertanyaan dan mendapatkan jawaban ini merupakan strategi pembentukan tim yang melibatkan siswa dalam peninjauan pelajaran. Dan cara yang dapat menimbulkan minat dan partisi siswa dalam hal ini yaitu dengan membuat teka-teki silang yang dapat di isi perorangan maupun secara kelompok.

2. Penilaian diri : dengan membuat penilaian pada sendiri akan dapat memudahkan untuk mengetahui perubahan pengetahuan yang kita dapat selama ini, melihat sampai sejauh mana keterampilan yang kita punyai dan seberapa besar materi pelajaran yang dapat kita terapkan dalam diri kita yang tercermin melalui sikap yaitu dengan mengemukakan pandangan mereka pada setiap siswa mengenai materi yang didapat diawal pertemuan samapai pada akhir pelajaran. Dari penilaian pada siswa diajak untuk menilai sendiri tentang apa yang dapat untuk dimanfaatkan dari pelajaran tersebut. Ini bertujuan dengan harapan pada setiap siswa tentang pelajaran tersebut bukan hanya sekedar mengikuti saja. 
3. Perencanaan masa mendatang merupakan salah satu strategi untuk siswa agar terus mempelajari mata pelajaran yang telah kita ajarkan karena bila kita sudah tidak mengajari lagi bukan berarti pelajaran tersebut telah berakhir namun sebaiknya siswa dapat belajar secara mandiri dengan gaya belajar yang telah dipunyainya, dan membuat komitmen yang benar-benar dapat memacu diri sendiri untuk terus belajar mengingat pelajaran yang lalu.

4. Ungkapan perasaan. Diakhir mata pelajaran agama usai setiap siswa yang telah dekat dengan siswa lainnya diharapkan dapat menyampaikan apa yang ada dalam pikirannya, perasaan dan masalah pelajaran lainnya, agar suasana lebih semarak maka diperlukan strategi-strategi yang menyenangkan dan tak terlupakan sehingga pelajaran yang disampaikan oleh guru masih dapat diingat dan diperaktekkan. Salah satu caranya adalah menjamin hubungan yang telah terjalin dan saling mengungkapkan perasaan-perasaan yang dialami selama proses belajar, saling berbagi cerita di pengalaman yang telah diperaktekkan, mengadakan tanya jawab dengan tujuan agar lebih mempereraktkan materi pelajaran yang telah selesai dan masih banyak cara lain yang lebih menyenangkan yang membuat siswa lebih aktif dalam pembelajaran.

\subsection{Urgensi Pembelajaran Aktif}

Belajar aktif tidak hanya diperlukan untuk menambah kegairahan namun juga untuk menghargai perbedaan individual dan beragamnya kecerdasan. Belajar memerlukan kedekatan mental sebelum memahami materi yang hendak dipelajari. Balajar bukan sekedar pengulangan atau hafalan dan praktek semata, belajar akan lebih efektif bila dibarengi juga dengan keaktifan siswa untuk dapat mengupayakan dalam pemecahan masalah. Pembelajaran aktif dapat mengembangkan kecakapan belajar, strategi belajar dan kebiasaan belajar yang fokus. Dengan pembelajaran aktif juga dapat mengembangkan kemampuan menerapkan prinsip-prinsip dan generalisasi yang telah dipelajari pada situasi dan masalah yang baru.

Dengan semakin berkembangnya zaman semakin maju pengetahuan maka guru dituntut untuk dapat menggunakan strategi mengajar yang lebih inovatif sesuai dengan tujuan dari pembelajaran aktif. Tentu dituntut untuk mengajarkan siswanya agar dapat aktif dan lebih kreatif dalam mengembangkan bakat serta dapat menghayati hal-hal yang dipelajari melalui percobaan dan praktek secara berkelompok atau sendiri sehingga guru disini hanya berperan sebagai fasilitas dan motivator bagi setiap siswa. Pembelajaran aktif dapat berpengaruh terhadap cara belajar siswa dalam hal memberikan tugas rutin bagi siswa dan memberikan kesempatan siswa untuk mengembangkan kemampuan mereka, memberikan satu titik fokus kepada kreatifitas dan kognitif siswa dari aspek 
prosedur dan memberikan penekanan kebolehan atas apa yang disampaikan siswa, handling dan dapat melakukan pengukuran (Measuring) atas kemampuan mereka.

Setiap pembelajaran adalah tindakan kreatif pembelajaran, tanpa adanya sumber daya kreasi pembelajar dalam proses belajar mengajar maka tidak ada sesuatu yang dipelajari. Karena itu, daya kreasi yang baik dapat membawa dampak pada pembelajaran yang baik dan pembelajaran yang baik menghasilkan daya kreasi yang baik. yang paling penting adalah bagaimana membuat siswa menjadi aktif, sehingga mampu pula mengerjakan tugas-tugas yang menggunakan kemampuan berpikir yang lebih tinggi, seperti menganalisis, membuat sintesis dan mengevaluasi. Dalam konteks ini, maka ditawarkanlah strategi-strategi yang berhubungan dengan belajar aktif. Dalam arti kata menggunakan teknik active learning (belajar aktif) di kelas menjadi sangat penting karena memiliki pengaruh yang besar terhadap belajar siswa.

\subsection{Macam-macam Strategi Pembelajaran aktif dan aplikasinya}

Strategi pembelajaran aktif ada empat strategi dasar dalam belajar mengajar yang meliputi hal-hal berikut :

1. Mengidentifikasi serta menetapkan spesipikasi dan kualifikasi perubahan tingkah laku dan kepribadian anak didik sebagaimana yang diharapkan.

2. Memilih sistem pendekatan belajar mengajar berdasarkan aspirasi dan pandangan hidup masyarakat.

3. Memilih dan menetapkan prosedur, metode, dan teknik belajar mengajar yang dianggap paling tepat dan efektif sehingga dapat dijadikan pegangan oleh guru dalam menunaikan kegiatan mengajarnya.

4. Menetapkan nama-nama dan batas minimal keberhasilan atau criteria serta standar keberhasilan sehingga dapat dijadikan pedoman. Dalam melakukan evaluasi hasil belajar mengajar yang selanjutnya akan dijadikan umpan balik buat penyempurnaan sistem instruksional yang bersangkutan secara keseluruhan.

Model active learning (belajar aktif) sebagai berikut "Dialog dengan diri sendiri adalah proses di mana siswa mulai berpikir secara reflektif mengenai topik yang dipelajari”. Mereka menanyakan pada diri mereka sendiri mengenai apa yang mereka pikir atau yang harus mereka pikirkan, apa yang mereka rasakan mengenai topik yang dipelajari. Pada tahap ini guru dapat meminta siswa untuk membaca sebuah jurnal atau teks dan meminta mereka menulis apa yang mereka pelajari, bagaimana mereka belajar, apa pengaruh bacaan tersebut terhadap diri mereka. Dialog dengan orang lain bukan dimaksudkan sebagai dialog parsial sebagaimana yang terjadi pada pengajaran tradisional, tetapi dialog yang lebih aktif dan dinamis ketika guru membuat diskusi kelompok kecil tentang topik yang dipelajari. Observasi terjadi ketika siswa memperhatikan atau 
mendengar seseorang yang sedang melakukan sesuatu hal yang berhubungan dengan apa yang mereka pelajari, apakah itu guru atau teman mereka sendiri. Doing atau berbuat merupakan aktivitas belajar di mana siswa berbuat sesuatu, seperti membuat suatu eksperimen, mengkritik sebuah argumen, atau sebuah tulisan dan lain sebagainya.

Untuk mendukung suasana belajar yang lebih kondusif maka guru/pengajar harus dapat menciptakan sebuah proses pembelajaran aktif yang baik, diantaranya adalah sebagai berikut :

a. Guru perlu berpengetahuan, memilki keahlian dan memahami bagaimana membuat suatu keputusan dan mampu membuat siswa merasa nyaman dengan pelajaran yang diberikan.

b. Peranan guru sangat penting bagi seorang guru untuk dapat memainkan posisinya dalam pelajaran yang diajarkannya, member penjelasan yang singkat dan jelas. Memberi bantuan kepada siswa untuk dapat menyelesaikan permasalahan terhadap soal-soal yang sulit dimengerti.

c. Mengenal dengan pasti hasil pembelajaran yang sesuai, menyusun kegiatan-kegiatan, penstrukturan dan tahap-tahap penting dalam pembelajaran.

Ada banyak metode yang dapat digunakan dalam menerapkan active learning (belajar aktif) dalam pembelajaran di sekolah. Mel Silberman mengemukakan 101 bentuk metode yang dapat digunakan dalam pembelajaran aktif. Kesemuanya dapat diterapkan dalam pembelajaran di kelas sesuai dengan jenis materi dan tujuan yang diinginkan dapat dicapai oleh anak. Metode tersebut diantaranya Question Student Have (Pertanyaan Peserta Didik), reconnecting (menghubungkan kembali), dan lain sebagainya".

\section{Question Student Have (Pertanyaan Peserta Didik)}

Metode Question Student Have ini digunakan untuk mempelajari tentang keinginan dan harapan siswa sebagai dasar untuk memaksimalkan potensi yang mereka miliki. Metode ini menggunakan sebuah teknik untuk mendapatkan partisipasi siswa melalui tulisan. Hal ini sangat baik digunakan pada siswa yang kurang berani mengungkapkan pertanyaan, keinginan dan harapan-harapannya melalui percakapan. Adapun prosedur yang diterapkan dalam metode ini adalah sebagai berikut :

1. Bagikan kartu kosong kepada siswa.

2. Mintalah setiap siswa menulis beberapa pertanyaan yang mereka miliki tentang mata pelajaran atau sifat pelajaran yang sedang dipelajari.

3. Putarlah kartu tersebut searah keliling jarum jam. Ketika setiap kartu diedarkan pada peserta berikutnya, peserta tersebut harus membacanya dan memberikan tanda cek di sana jika 
pertanyaan yang sama yang mereka ajukan.

4. Saat kartu kembali pada penulisnya, setiap peserta telah memeriksa semua pertanyaan yang diajukan oleh kelompok tersebut. Fase ini akan mengidentifikasi pertanyaan mana yang banyak dipertanyakan. Jawab masingmasing pertanyaan tersebut dengan :

a. Jawaban langsung atau berikan jawaban yang berani

b. Menunda jawaban dari pertanyaanpertanyaan tersebut sampai waktu yang tepat

c. Meluruskan pertanyaan yang tidak menunjukkan suatu pertanyaan\

5. Panggil beberapa peserta berbagi pertanyaan secara sukarela, sekalipun pertanyaan mereka tidak memperoleh suara terbanyak.

6. Kumpulkan semua kartu. Kartu tersebut mungkin berisi pertanyaan-pertanyaan yang mungkin dijawab pada pertemuan berikutnya.

\section{Reconnecting (menghubungkan kembali)}

Metode reconnecting (menghubungkan kembali) ini digunakan untuk mengembalikan perhatian siswa pada pelajaran setelah beberapa saat tidak melakukan aktivitas tersebut. Adapun prosedur yang diterapkan dalam metode ini adalah sebagai berikut :
1. Ajaklah siswa kembali kepada pelajaran. Jelaskan pada siswa bahwa menghabiskan beberapa menit untuk mengaitkan kembali pelajaran dengan pengetahuan anak akan memberi makna yang berarti.

2. Tentukan satu atau lebih dari pertanyaan-pertanyaan berikut ini kepada para peserta didik

a. Apa saja yang masih anda ingat tentang pelajaran terakhir kita? apa saja yang masih bertahan dalam diri anda?

b. Sudahkah anda membaca / berpikir / melakukan sesuatu yang dirangsang oleh pelajaran terakhi kita?

c. Pengalaman menarik apa yang telah anda miliki di antara pelajaranpelajaran?

d. Apa saja yang ada dalam pikiran anda sekarang (misal nya sebuah kekhawatiran) yang mungkin mengganggu kemampuan anda untuk memberi perhatian pebuh terhadap pelajaran hari ini?

3. Dapatkan respons dengan menggunakan salah satu format, seperti sub-kelompok atau pembicara dengan urutan panggilan berikutnya.

4. Hubungkan dengan topik sekarang

\subsection{Karakteristik Pembelajaran Aktif}

Sekolah yang melakukan pembelajaran 
aktif dengan baik harus mempunyai karakteristik, diantaranya yaitu:

1. Pembelajaran berpusat pada siswa. Siswa berperan lebih aktif dalam mengembangkan cara-cara belajar mandiri. Siswa berperan serta pada perencanaan, pelaksanaan dan penilaian proses belajar. Pengalaman siswa lebih diutamakan.

2. Guru membimbing dalam terjadinya pengalaman belajar. Guru bukan satusatunyasumberbelajar. Gurumerupakan salah satunya sumber belajar, yang memberikan peluang bagi siswa agar dapat memperoleh pengetahuan atau ketrampilan sendiri melalui usaha sendiri, dapat mengembangkan motivasi dari dalam dirinya, dan dapat mengembangkan pengalaman untuk membuat suatu karya.

3. Tujuan kegiatan pembelajaran tidak hanya untuk sekedar mengejar standar akademis. Selain pencapaian standar akademis, kegiatan ditekankan untuk mengembangkan siswa secara utuh dan seimbang.

4. Pengelolaan kegiatan pembelajaran ditekankan pada kreativitas siswa, dan memperhatikan kemajuan siswa untuk menguasai konsep-konsep dengan mantap.

5. Penilaian dilakukan untuk mengukur dan mengamati kegiatan dan kemajuan siswa, serta mengukur ketrampilan dan hasil belajar siswa.

\section{Kesimpulan}

Pembelajaran aktif (Active Learning) adalah suatu proses pembelajaran yang tujuannya untuk memberdayakan peserta didik agar belajar menggunakan berbagai cara atau strategi secara aktif, dengan maksud untuk mengoptimalkan penggunaan semua potensi yang dimiliki oleh siswa, sehingga semua siswa dapat mencapai hasil belajar yang memuaskan sesuai dengan karakteristik pribadi yang mereka miliki. Prinsip pembelajaran aktif adalah suatu proses pembelajaran yang lebih menekankan pada siswanya untuk dapat aktif dalam mengembangkan bakat keterampilan, mengasah pengetahuannya dan menciptakan suasana belajar terdiri bagi dirinya sehingga akan tercipta suasana belajar yang lebih nyaman dan lebih mudah dalam memahami pelajaran yang disampaikan oleh guru.

Ada banyak metode yang dapat digunakan dalam menerapkan active learning (belajar aktif) dalam pembelajaran di sekolah. Mel Silberman mengemukakan 101 bentuk metode yang dapat digunakan dalam pembelajaran aktif. Kesemuanya dapat diterapkan dalam pembelajaran di kelas sesuai dengan jenis materi dan tujuan yang diinginkan dapat dicapai oleh anak. Metode tersebut diantaranya Question Student Have (Pertanyaan Peserta Didik), reconnecting (menghubungkan kembali), dan lain sebagainya". Karakteristik pembelajarn aktif diantaranya: Pembelajaran berpusat pada siswa, guru harus membimbing peserta didik, 
tujuan pembelajaran tidak sekedar untuk memenuhi standard akademis, menekankan pda kreativitas siswa.

\section{Daftar Pustaka}

Drs. Syaiful Bahri Djamarah dan Drs. Aswin Zain.1997. Strategi Belajar Mengaja Penerbit Bineka Cipta

Melvin L.Siberman,(terjemah:Raisul Muttaqiem).2004.101 Active Learning Cara Belajar Siswa Aktif. Bandung :PT. Nuansa,Cet

Hisyam Zaini. 2004.Strategi Pembelajaran Aktif, Edisi revisi. Yogyakarta:CTSD Center for Teaching Staff Development

Moh.Uzer Usman. 2000.Upaya Optimalisasi Kegiatan Belajar Mengajar Bandung:PT. Remaja Rosda Karya

Oemar Hamalik.1990. Strategi Belajar Mengajar .CV.Mandur Maju

Sanjaya, Wina. 2006. Strategi Pembelajaran. Bandung: Prenadamedia Group. 